Article

\title{
Evaluating 4D-BIM and VR for Effective Safety Communication and Training: A Case Study of Multilingual Construction Job-Site Crew
}

\author{
Muneeb Afzal and Muhammad Tariq Shafiq *iD
}

check for updates

Citation: Afzal, M.; Shafiq, M.T. Evaluating 4D-BIM and VR for Effective Safety Communication and Training: A Case Study of Multilingual Construction Job-Site Crew. Buildings 2021, 11, 319. https://doi.org/10.3390/buildings11080319

Academic Editor: Svetlana J. Olbina

Received: 24 April 2021

Accepted: 22 July 2021

Published: 26 July 2021

Publisher's Note: MDPI stays neutral with regard to jurisdictional claims in published maps and institutional affiliations.

Copyright: (c) 2021 by the authors. Licensee MDPI, Basel, Switzerland. This article is an open access article distributed under the terms and conditions of the Creative Commons Attribution (CC BY) license (https:// creativecommons.org/licenses/by/ $4.0 /)$.
Department of Architectural Engineering, College of Engineering, United Arab Emirates University, Al Ain 155551, United Arab Emirates; muneeb.afzal@uaeu.ac.ae

* Correspondence: muhammad.tariq@uaeu.ac.ae

Abstract: Effective safety management is a key aspect of managing construction projects. Current safety management practices are heavily document-oriented that rely on historical data to identify potential hazards at a construction job site. Such document-bound safety practices are prone to interpretative and communication errors in multilingual construction environments, such as in the United Arab Emirates (UAE). Applications of Building Information Models (BIM) and Virtual Reality (VR) are claimed to improve hazards identification and communication in comparison to 2-D static drawings by simulating job-site conditions and safety implications and thus can interactively educate the job-site crew to enhance their understanding of the on-site conditions and safety requirements. This paper presents findings of a case study conducted to evaluate the effectiveness of 4-Dimensional (4-D) BIM and VR in simulating job-site safety instructions for a multilingual construction crew at a project in the UAE. 4-D BIM-enabled VR simulations, in lieu of the Abu Dhabi Occupational Safety and Health Center (OSHAD) code of practice, were developed and tested through risk assessment and safety training exercises for the job-site crew. The results showed a significant improvement in the job-site crew's ability to recognize a hazard, understand safety protocols, and incorporate proactive risk response in mitigating the hazards. This study concludes that 4-D BIM-enabled VR visualization can improve information flow and knowledge exchange in a multilingual environment where jobsite crew do not speak a common language and cannot understand written safety instructions, manuals, and documents in any common language due to linguistic diversity. The findings of this study are useful in communicating safety instructions, and safety training, in the UAE, as well as in international projects.

Keywords: 4D BIM; simulation; multilingual work environment; virtual reality (VR); building information modeling (BIM); safety training; occupational health and safety (OHS)

\section{Introduction}

The construction sector in the United Arab Emirates (UAE) is ranked among the leading industries in the world. The construction industry of the UAE has grown rapidly since the last decade, and further growth is expected in the future. To accommodate strategic goals, the UAE has invested considerably in the infrastructure sector [1]. The UAE witnessed a dynamic increase in construction activities, with the awarding of Expo 2020 [2], which has now been postponed to 2021 owing to the ongoing COVID-19 pandemic [3]. Several mega-projects are already underway and the UAE's construction projects expenditures are projected to reach US\$14 tn by the year $2025[1,4]$.

Considering the complexity and time constraints of construction projects, all construction job sites require safety orientation and training, which places additional responsibility on workers to ensure requisite capacity building within a short time and simultaneously complying with the rules and regulations during the designing, planning, and execution of tasks $[5,6]$. This situation worsens in multilingual construction environments, such as those 
in the UAE, where the construction workforce is an amalgam of personnel with varying ethnical backgrounds [2], nationalities, educational qualifications, and religious beliefs [7]. For example, most of the top tier of the workforce in the UAE belong to Gulf Cooperation Council (GCC) countries, and native English speaking staff, including expats from the USA, UK, Europe, Australia, and Canada. Some of the middle management comprises engineering professionals from Pakistan, India, the Philippines, Egypt, and Jordan [8,9]. The lower tier of the construction workforce corresponds to trade workers and labourers from several south Asian countries, including Pakistan, India, Bangladesh, and Nepal [10]. Although this diversity attracts a skilled workforce, there may be adverse effects on occupational health and safety (OHS) owing to communication problems arising from differences in dialects and languages [11]. For example, safety planning and decision-making are performed at the top and middle levels of the construction workforce, who use English and Arabic as a language for communication. The lower tier that executes the on-site tasks generally cannot understand Arabic or English and does not have any common language that can be used to effectively convey safety knowledge and instructions. Hence, safety instructions have to be translated into several languages (e.g., Urdu, Hindi, Punjabi, Bengali, Tamil, and Pashto), which is a time-consuming, error-prone, and ineffective process.

The UAE has efficient regional departments to ensure OHS, such as Dubai Municipality (DM), Dubai Technology and Media Free Zone Authority, and Department of Planning and Development-Trakhees, for Dubai, and Occupational Safety and Health Abu Dhabi (OSHAD) for Abu Dhabi. However, they follow the UAE OHS Management System (OHSMS), which does not address the communication barrier in a multilingual environment. This management system is provided by the National Crisis Emergency and Disasters Management Authority (NCEMA); in addition to NCEMA, the interstate authorities use their safety code, manuals, and regulations, which help the construction stakeholders follow a protocol to ensure safety in their jurisdiction [12]. According to OSHMS [13], hazard identification for safety lapses depends on brainstorming sessions wherein safety threats are identified and recorded in a preliminary hazard list (PHL). This process includes site visits and staff interviews. PHL can also be created by an experienced staff who considers safety-related knowledge to predetermine any safety lapses. This is a document-driven process and leads to many safety threats being ignored owing to a lack of visualization. Hence, it becomes difficult to devise a robust safety plan.

Technology is believed to be a solution to address these problems and other safetyrelated issues to mitigate construction safety threats [14]. The high accident rates in the construction industry in comparison with other sectors [15]; manufacturing and production, are attributed to the fact that construction sites are less controllable, unlike other sectors where most tasks are pre-defined and repetitive [16]. Within construction informatics, building information modelling (BIM) is a technology driven process that can provide reliable data using 3D models to make informed decision making [17]. BIM uses objectoriented modelling to create data-rich 3D models that can capture and provide data throughout the lifecycle of a construction project. BIM models can provide numerous benefits, including visualization and manipulation of accurate data to resolve conflicts and communication errors $[18,19]$. Studies have shown that BIM models can help to reduce the number of job-site fatalities and injuries and to enhance the overall safety environment [20-22]. BIM comprises several stages of construction, ranging from two dimensions to n-dimensions [23]. Within these dimensions, time is the fourth dimension of BIM, and it is the projection of three-dimensional (3D) BIM models depicting project delivery [24]. The $4 \mathrm{D}$ BIM simulation consists of step-by-step 3D visualizations of the construction activities projected across the project timeline [25]. According to Boton [25], $4 \mathrm{D}$ simulations can be very useful for site meetings and project reviews to discuss the progress and alternatives of real-time conditions in comparison with forecasts. Thus, the step-by-step visual progression of the project can also be highly effective in site safety planning and management. Further, 4D BIM can also be integrated with virtual reality (VR) to help the user visualize the $4 \mathrm{D}$ simulation in an immersive environment. 
VR is also being increasingly used in the construction sector to improve construction safety. VR is defined as the technology that enables the user to completely immerse in a virtual environment through computer-generated simulations [26]. With these symbolic representations, VR helps the user visualize and obtain a greater understanding of the project [27]. Thus, the actual project can be visualized through VR simulation, giving the decision-makers a chance to visualize, evaluate, and mitigate risks before on-site execution. The effectiveness of the emerging technologies to improve different aspects of construction safety has been extensively studied. However, previous research [28] did not consider a multilingual workspace environment, which may lead to many safety lapses due to the lack of proper communication and language barrier.

This paper presents the findings of a case study conducted to evaluate the effectiveness of 4-Dimensional (4-D) BIM and VR in simulating job-site safety instructions for a multilingual construction crew at a project in the UAE. 4-D BIM-enabled VR simulations, in lieu of the Abu Dhabi Occupational Safety and Health Center (OSHAD) code of practice, were developed and tested through risk assessment and safety training exercises for the job-site crew. This research hypothesizes that advanced technologies, such as 4D BIM and VR, can help ensure construction safety by improving the information flow in a multilingual environment. Using these technologies, project teams can rapidly evaluate possible safety scenarios throughout the execution of the project and thereby develop the hazard identification and cognition abilities of on-site workers.

\section{Background Research}

\subsection{Limitations of Traditional Construction Safety Practices}

The traditional construction health and safety (H\&S) process can be divided into two phases, namely, preconstruction and construction phases [29]. During the preconstruction or design phase, the safety concerns are usually identified based on the prior experience of the safety panel (H\&S experts, design engineers, or project managers) [30]; safety planning and safety training sessions are conducted as a measure against these threats. During the construction phase, safety hazards are mitigated by job-site monitoring [31]. Since the number of occurrences of fatality in the construction sector far exceeds that in other industries, the conventional construction H\&S methodology is regarded inefficient [32]. Typical construction safety management consists of four steps: (1) safety induction, (2) safety site planning, (3) safety monitoring, and (4) safety training.

Construction safety induction is the process of acquainting the workers with siterelated H\&S issues that impede the construction progress and productivity of the site operations [33]. According to Ganah [33], because on-site operations change over time and hazards differ from one project to another, they cannot be generalized. Owing to poor safety induction [34-36], new workers joining a team are not well aware of the possible threats on-site; hence, safety lapses are expected. This discrepancy in the induction process sets up the safety plan for failure. According to Azhar [11], a typical safety plan should address such questions: When would a safety hazard may occur? Where would the safety hazard may occur? And why the safety hazard occur? Usually, the exercise of safety site planning is devised through a team meeting in which 2D drawings, schedules, safety regulations, and previous experiences are discussed to identify and tackle the future hazards that on-site workers may face $[30,37]$. The inefficiency of these methods owing to lack of visualization has been well documented in research, and such a document-oriented approach is criticised for being error-prone [37-39]. Another important document that is utilized during the traditional safety planning process for preparing risk assessment is a method statement document. According to Carter [31], this document lays out the description, location, and sequence of work in terms of its health, safety, and environmental impact. Method statements do not provide a robust safety planning mechanism, as they are generic documents that do not deal with every accident scenario, are inaccessible to the on-site execution workers [40] and lack visualization. During the project execution, the safety plan is ensured via job-site monitoring. 
For construction site monitoring and inspection, safety managers have to check the current situation of workers, materials, and equipment [41,42] during on-site execution. These safety monitoring practices rely on manual inspection, which is error-prone, as it is very difficult for safety inspectors to identify manually all the incidents to which the workers are exposed [43]. They often use a checklist to identify and record violations [44]. Considering the dynamic nature of the construction industry [45,46], and lack of visualization owing to the absence of digital tools, any variation in construction information only impede construction monitoring since safety workers and offices depend heavily on construction drawings, specifications, and related documents [30]. To ensure that the labourers do not make mistakes in on-site work, they are communicated the potential hazards through safety training. Traditionally safety-related capacity building is conducted via lectures, seminars, workshops, animations, Microsoft PowerPoint presentations, and supporting documents [47]. However, these means of training are not effective for the construction workforce, especially if the construction crew belongs to diversified ethnic backgrounds [48,49]. Construction workers are experiential learners who tend to lose interest in memorizing safety instructions, lack continuous engagement with these approaches, and prefer more proactive learning styles [50].

Traditional health and safety practices rely heavily on documentation, which may not always depict the actual site conditions. Therefore, traditional H\&S processes are long, heterogeneous, complex, and redundant [51]. Hence, generally, these processes do not accomplish the purpose of safety mitigation. As per Martínez-Rojas et al. [51], the major drawbacks of the H\&S documentation are that it comprises unstructured information, which is based on generalized risk calculation and mitigation strategies and lacks relevant information. Considering the myriad problems in the traditional H\&S mechanisms, researchers and policymakers have explored innovative ways of mitigating job-site risks and promoting a safety culture.

\subsection{Construction Safety Challenges Arising in a Multilingual Environment}

Construction safety practices are difficult to ensure in a multilingual environment [52]. The language barrier hampers the progress of construction in many ways [53-56], especially, when the workforce comprises foreign labourers. For example, in Malaysia, Bengali and Nepali labourers are involved in job-site execution, whereas the supervisors who communicate in the native language are involved in decision making and information exchange [56]. This leads to unnecessary delays and safety complications.

A similar scenario is observed in the US construction industry, where $20 \%$ of the construction force is foreign-born workers [57]. As per Demirkesen and Arditi [55], some of these workers can communicate in English, while others do not understand the language at all. Dai and Goodrum [58] mention that the Hispanic workers employed in the construction sector in the US cannot communicate properly in English as they understand and speak Spanish. Hence, they are more prone to safety threats. Studies conducted in Singapore and Korea $[59,60]$ showed that language and communication barriers are the major hindrances that affect the progress and productivity of construction projects.

The complex communication dynamics between different strata of human resources were reported in previous studies. As per Bust et al. [61], the interaction between foreignborn workers and local teams (staff and workers) is difficult. Because of the language barrier, migrant workers cannot fully comprehend the specific instructions provided by the site foreman [62]. If safety planning is conducted during the design phase, for example [63-65], the information permeates through three levels of the workforce, that is, the designer/project manager, safety panel, and on-site workers, and is finally implemented on-site. It is very difficult to ensure that the instructions laid out by the decision-makers reach the job site first-hand and are implemented in the same manner as instructed. 


\subsection{Significance of Digital Design Technologies for Safety Planning and Capacity Building}

To solve the problems of document-bound safety management practices and language barriers in construction sites, several researchers presented different visualization aids as a solution for effective safety management and communication. Many virtual design technologies [66], such as BIM [67-69], VR [27,70,71], Augmented Reality (AR) [72-74], radio-frequency identification devices [75,76], serious games [77,78], and Geographic Information System $[79,80]$ were proposed for site hazard prevention and safety management. The use of these technologies led to the improvement of project delivery. These technologies are mainly designed to capture, design, analyze, store, manipulate, and visualize the information of the construction project. Rajendran et al. [81] suggests that incorporating digital technologies into the traditional safety methods can lead to benefits such as efficient safety planning, safety design, safety training, accident investigation, and facility management.

This study is limited to evaluating the effectiveness of $4 \mathrm{D}-\mathrm{BIM}$ and VR in improving the traditional construction safety processes. The following sections present work related to the application of $4 \mathrm{D}$ BIM and VR for safety management.

\subsection{Building Information Modeling}

The virtual timeline of the construction project or stepwise visuals for the construction activities can help decision-makers visualize the construction sequence before execution. Thus, the project teams can recognize hazards and evaluate site conditions in a much better manner than that possible with the traditional 2D drawings [37]. Different studies have explored the potential of 4D BIM for safety planning and related applications [37, 82-86]. For example, in GCPSU 2009, a BIM-based 4D system was devised to resolve safety-related issues such as points of conflict and structural safety [86]. Similarly, Shang et al. [82] devised a 4D-BIM-based framework to avoid collision hazards by modelling and analyzing workspaces. The 4D BIM can improve safety by overlapping it with planning, laying out safety plans, and foreseeing updated plans and site-related information. Onsite workers can benefit from this information and probable risks can be averted [87]. Choe et al. [86], presented a case study in which parameters such as safety knowledge, time, spatial information, schedule, and 3D model are integrated to devise a proactive strategy for safety planning to avert any safety incident. Similarly, Choi et al. [85] proposed a framework based on activity, space, and a plan to establish a 4D BIM environment for improving spatial incidents. Further, 4D BIM can be useful to evaluate temporary structures and convey threats throughout the project [37], and the technology can especially be useful for safety management of mega-scale projects such as metro transport networks [83]. Further, similar to other digital technologies, 4D BIM can also be helpful for safety-related capacity building. Miller et al. [78] integrated 4D BIM and game technologies to present an effective way of skill learning for construction safety. The effectiveness of safety training depends upon how a user interacts with the technology at hand. 4D BIM can create an interactive environment, providing advantages over the traditional safety learning techniques such as lecture-based training and the use of animations and pictures.

\subsection{Virtual Reality}

Several studies [88-94] have showed that VR has a strong potential to be a more effective tool for safety communication and training compared to traditional methods. VR can help visualize the problems that may arise with any mismanagement on-site [27]. Hence, the use of VR and evaluation of its level of real-world immersion have been actively researched. VR increases engagement [70], and the headsets provide the user with reallife-like immersion [71]. Teizer et al. [95] integrated location tracking and VR for training ironworkers. VR-based training can be replayed several times, making them useful. It is very difficult to make the workers realize the gravity of electrical hazards, especially with conventional training methods such as lectures and presentations. Hence, it becomes difficult to teach them the necessary measures that need to be taken to avoid such hazards. 
VR technology is a helpful resource for electrical hazard training and gives a real-life-like feel that is ethically impossible to test [96].

Regarding the built environment, typically VR projections are generated by importing BIM-based models into gaming engines such as Unreal Engine or Unity 3D. The final immersion is experienced through head-mounted devices (HMD) [97]. VR immersion can be experienced either through a VR HMD in which screens are placed in front of the eyes or through a visualization that can be observed by other users with two big projection screens. This later type of VR environment is called Cave Automatic Virtual Environments (CAVE) [88]. To improve construction safety, Sacks et al. [89] used the CAVE system to increase collaboration between design and execution teams. The CAVE setup helped the stakeholders detect, discuss, and mitigate safety hazards. Since it is impractical to create hazardous site conditions for safety training, CAVE systems expose the user to realistic unsafe conditions without actually putting them in danger. Hence, well-designed VR environments can be excellent not only for detecting potential hazards but also for training workers to resolve them on-site.

Research studies also compared the effectiveness of the traditional training methodologies (paper-based, lectures, and seminars) with modern VR-based immersive training. For example, Pedro et al. [90] compared the effectiveness of the traditional methods of training with that of the Virtual Safety Education Framework (VSES), a system for safety training. VSES consisted of various safety scenarios based on safety documents projected in VR. The results showed that VSES was more efficient in helping students understand safety concepts, improving their overall safety-related knowledge. According to Sacks et al. [91], virtual training was a more effective mode of learning compared to classroom methods. VR training results in more retention of attention for trainees, whereas the conventional safety training, lectures, and videos do not captivate the user to get them fully engaged owing to their lower retention rates.

Le et al. [92] integrated Second Life with VR to provide safety training to students. The role-playing aspect of the game improved knowledge about safety accident scenarios. This training methodology was more effective than the traditional training. Luo et al. [94] developed two versions of a multiuser VR-based application. The desktop version included leap motion and a joystick, whereas the mobile-based version incorporated VR via Samsung Gear VR. Similarly, Mo et al. [93] improved safety training using a data-driven approach. Typically, VR training is case/accident specific. The data-driven approach helped generate safety scenarios automatically. The study analyzed the data of 232 cases, clustering them into eight parameters. VR-based scenarios were generated using Unity 3D, based on these eight parameters. The training was highly effective and considered the major on-site safety threats holistically.

The review of digital technologies showed that $4 \mathrm{D}$ BIM and VR can be effective tools for improving safety hazard identification and training. The UAE construction industry also faces the unique challenge of ensuring effective safety communication against the background of the linguistic diversity of the construction job-site crew. The UAE attracts a diverse construction workforce for a large number of ongoing and planned construction projects. Quantitative research [6] showed a major difference between the language spoken for delivering instructions and that used by on-site workers. The same study indicated that English is used predominantly (70\%) to impart safety-related instructions, whereas the labourers on-site do not speak or understand this language owing to differences in nationality. This environment makes the construction sites in the UAE prone to different job-site hazards that could easily be avoided, provided that risk assessment and mitigation strategies are conveyed efficiently to the working tier on-site. Although the UAE the construction industry is using BIM for various purposes, its safety management methodologies do not integrate other IT-based virtual design and construction technologies (VDC) such as Radio-frequency identification (RFID), real-time location system (RTLS), VR, and AR. Therefore, there is a need to evaluate the effectiveness of using 4D BIM and VR for safety identification, training, and communication in a multinational, multilingual job-site crew. 


\section{Research Methodology}

The research methodology adopted for this study is based on a literature review and a case study that tested BIM-based VR simulations using fall hazard identification scenarios with a multilingual construction screw.

First, a literature review was conducted to investigate the problems of hazard identification and safety training techniques in the traditional safety planning practices, and the impact of a multilingual environment on construction H\&S. Subsequently, a state-of-the-art review of VDC technologies was performed, and 4D BIM and VR and their impact in improving construction safety were studied. The findings motivated the analysis of the potential of VR-based 4D simulation to enhance the risk assessment, hazard identification, and safety training within the context of the multilingual environment of the UAE. The technical feasibility of the VR-based 4D BIM simulation was analyzed through a real-time case study project to evaluate its efficiency in mitigating potential safety threats. In this study, only the falling hazard exercise conducted in the project was examined. Through a mixed-method approach, simulation trials and discussions were performed for the focus group to evaluate the effectiveness of the simulation. A mixed methods research method was used, as it is best suited for research in which qualitative and quantitative data are collected concurrently [98]. The initial research task was to develop BIM-based models that could be converted into a VR based simulation. The BIM based VR simulations were designed to meet OSHAD requirements for safety planning and comply with the regulations imparted to ensure fall hazard prevention.

The safety module administration consisted of testing the module within the construction staff. To minimize the effect of the language difference, the safety exercise was tested across the construction hierarchy (decision-makers and on-site workers). The construction staff was able to pinpoint, discuss and resolve major safety threats which were further explained to workers on-site. The workers on-site understood hazards and necessary precautions to avoid injuries. Later a survey solicited the opinions of participants regarding the impact of using five (5) Likert-scale aspects. Similar rating mechanisms have been applied in the studies $[99,100]$ where safety training modules were rated. They were also asked open-ended questions soliciting feedback and the effectiveness of the module. The details of the case study are presented in the following section.

This research comprised five stages, as shown in Figure 1.

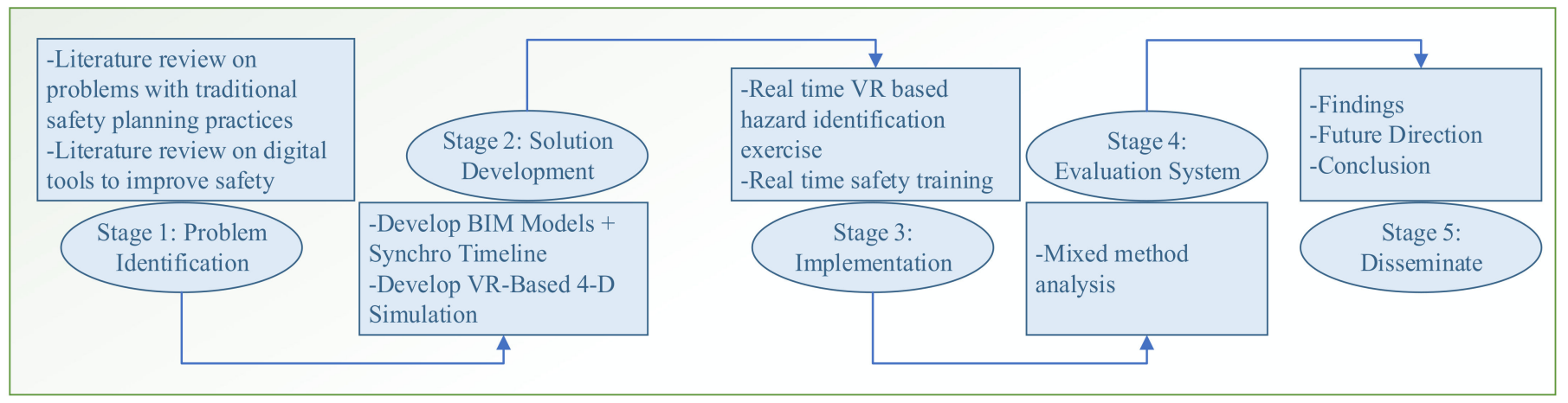

Figure 1. Research stages.

\subsection{Case Study}

The purpose of this case study was to test the 4D BIM-based VR simulation about mitigating the safety threats and to analyze the potential benefits and challenges of implementing digital tools in terms of safety planning. This study also examined whether the implementation of these tools ultimately improved safety-related communication in the multilingual construction industry of the UAE.

This case study used a residential building project, covering an area of $100,000 \mathrm{ft}^{2}$, located in Al-Ain in the state of Abu Dhabi (Eastern region) in the UAE. The project was initiated in August 2018 and initially planned to be completed by August 2020. However, 
the COVID-19 pandemic [101] eventually disrupted different sectors globally [102,103], including the construction industry in UAE. Due to the COVID-19 imposed Safe Operating Protocols (SOPs) [104] applied across the country, this project faced major challenges in execution and procurement, and the new completion date of the project was set as 31 January 2021.

Against this background, this case study was conducted in three phases to exchange knowledge, ensure proper awareness, identify hazards, and train workers.

In the first phase, a conceptual framework of this study was explained to the safetyrelated decision-makers of the project. The project under consideration was a good candidate for the research because the staff was an amalgam of people with different ethnicities and speaking different languages (Figure 2), and the project was newly started and no safety risk analysis had been conducted by the time of this study. Therefore, the project could potentially benefit from this study by implementing VR-based $4 \mathrm{D}$ safety simulation to ensure systematic safety management and planning. After the first meeting, necessary data such as $2 \mathrm{D}$ engineering drawings and zoning plans were obtained to develop a VRbased simulation. During the second meeting, the VR-based 4D simulation was tested with a project manager, a safety manager, a safety inspector, and concrete finisher labor as participants. During the third meeting, all results were reviewed, and the benefits and limitations were discussed with the participants of the project. The analysis period of the residential building was from October 2019 to January 2020. BIM models were generated to develop the VR safety simulation. Considering the complexity of actual construction, different remedial actions related to falling hazards during grey structure construction and architectural finishing execution were discussed.
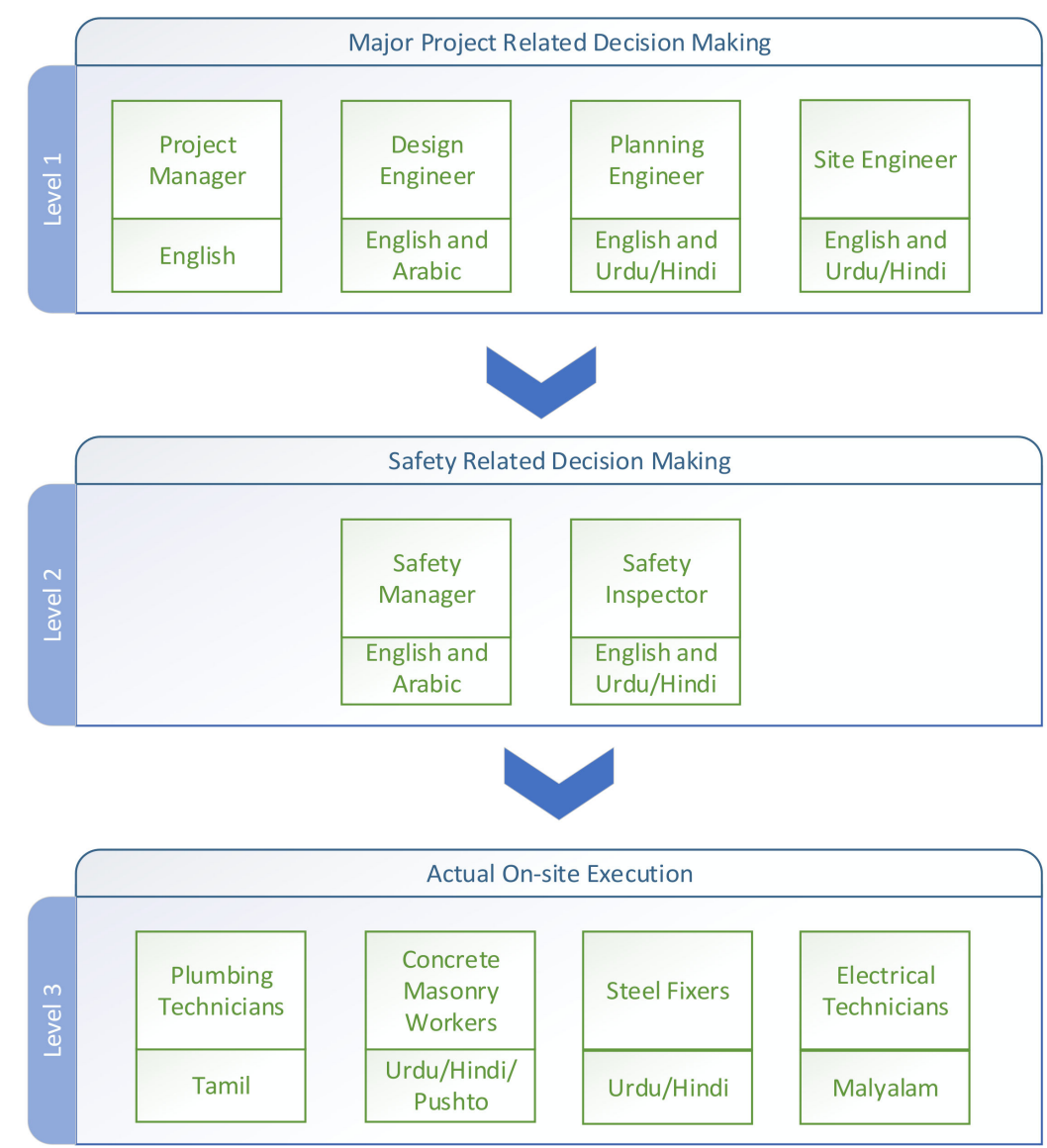

Figure 2. Language and hierarchical level representation of construction staff. 


\subsection{Design and Concept of Safety Modules and the Test Use-Cases}

The study aimed to enhance safety planning by improving proactive decision-making and increasing the hazard detection abilities of workers. The implementation process consisted of three stages, namely, safety assessment and awareness, safety cognition and training, and safety remedial action planning. The process was aimed to evaluate whether the usage of digital tools may improve safety-related communication among different teams working on a construction project. The functions and processes at each stage are shown in Figure 3.

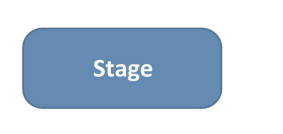

Function

Technology

Paticipants

Activity
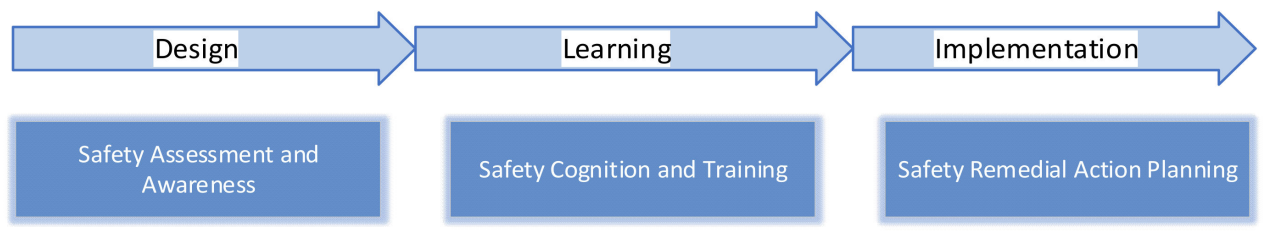

Knowledge Sharing

Hazard Identification

Hazard Mitigation Strategies

\section{BIM/Synchro Models}

and VR Simulation

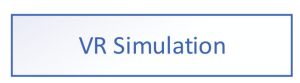

VR Simulation, Mobile
Devices and Projector

\section{Project Manager and}

Safety Experts

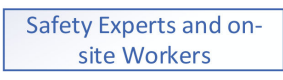

site Workers

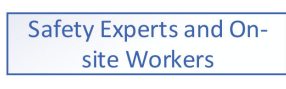

Safety Training Sessions
Focus Group Sessions
Safety Planning Sessions

Figure 3. Safety planning and training module used in the case study.

\subsubsection{Safety Assessment and Awareness}

In this stage, participants exchanged safety-related knowledge regarding the project to incorporate it into the VR-based training. The software-based 4D simulation helped the participants discuss various aspects of the project and share their relevant knowledge regarding predictable accidents, providing a stepping stone for the researchers to introduce VR-based digital content instead of document-based safety regulations. Since the study was performed in the Abu Dhabi region of UAE, OSHAD rules and regulations were applied. These knowledge exchange sessions lead to the refinement of the final VR-based training module. Brainstorming sessions, incorporating the OSHAD regulations, along with the expertise of the safety experts and the basic simulation helped build a systematic safety plan system. The knowledge exchange helps safety experts get introduced to digital tools, whereas it helps researchers improve VR-based safety simulation.

\subsubsection{Safety Cognition and Training}

The knowledge-sharing exchange was realized during the cognition and training stage, which provides a VR-based role-play opportunity for decision-makers to involve, predict, and identify hazards. This virtual content comprising OSHAD-based models of the real-time building helped experts predetermine the safety lapses that may have been missed initially owing to a lack of visualization in the 2D drawings. This exercise is based on identifying hazards digitally and then transferring the knowledge base to the on-site workers. After VR training, on-site workers are expected to develop hazard identification skills to avoid major safety threats. By taking the advantage of $4 \mathrm{D}$ simulation, the whole scenario-based training enables participants to experience the possible real situations they may encounter in the future during execution. This module not only helps in hazard identification but also trains the workers on the use of digital tools for safety capacity building. 


\subsubsection{Safety Remedial Action Planning}

To overcome the language barrier and improve the traditional safety planning, the workers on-site were introduced to the remedial action plans for each of the safety threats that they may encounter. Safety hazards predetermined by the experts in the previous module are communicated to and visualized by the workers until they understand the problem. This exercise is continued until the panel gets a complete understanding of the safety concern. This process is repeated by each team of the particular discipline (electrical, mechanical, and architectural finishing workers). Finally, the participants are provided with formal training based on OSHAD provisions to help them mitigate the probable threat.

\subsection{Design and Development of Test Simulations}

The simulation comprises three main components, namely, the planning, modelling, and visualizing components. The planning and modelling components are the platforms where data are inserted as an input for creating the safety simulation to be displayed via the visualizing component. The planning component considers the timelines of individual activities to produce the project schedule. In this study, this schedule was formulated using Microsoft Project ${ }^{\circledR}$ (UAE University). For modelling, Autodesk Revit ${ }^{\circledR}$ (Student Version, UAE University) was used to produce BIM models. With the help of 2D drawings obtained from the contractor, individual BIM models were produced for the architecture, structure, and mechanical, electrical, and plumbing aspects. After producing the project schedule and the BIM models, the useful information provided by the models and schedule was utilized to produce a VR-based $4 \mathrm{D}$ simulation of the project. The models were imported to Autodesk $3 \mathrm{ds} \mathrm{Max}{ }^{\circledR}$ (Student Version, UAE University) to form a mesh to be imported into gaming software (Unreal Engine ${ }^{\circledR}$, Student Version, UAE University). The models along with the schedule were also imported to virtual planning software Synchro ${ }^{\circledR}$ (Student Version, UAE University) which is used to generate a $4 \mathrm{D}$ timeline that can provide a reference for Unreal Engine 4D animation and can make the on-site stakeholders aware of the digital safety planning. The visualization component of the setup is the most important part of the simulation as it helps the user interact with the developed simulation and assimilate with experience. A .fbx file was imported from 3ds Max to Unreal Engine software, where textures, materials, and lighting were added. Care was taken that the file type imported to the gaming engine was not complex or difficult for the system to process. The animation process for the timeline initially presented through Synchro was replicated in a VR environment. The final building model was the near-real visualization of the actual project building. The $4 \mathrm{D}$ representation of the building enabled the safety decision-makers to make major changes to the actual sequence of activities to be conducted on-site. Once the VR simulation was ready, users could experience VR immersion through the Oculus Rift headset (Purchased, UAE University). The file exchange between the software is depicted in Figure 4. For experiencing the visualization on-site, without VR headsets, an Android version (Unreal Engine, Student Version) of the simulation was also created. 


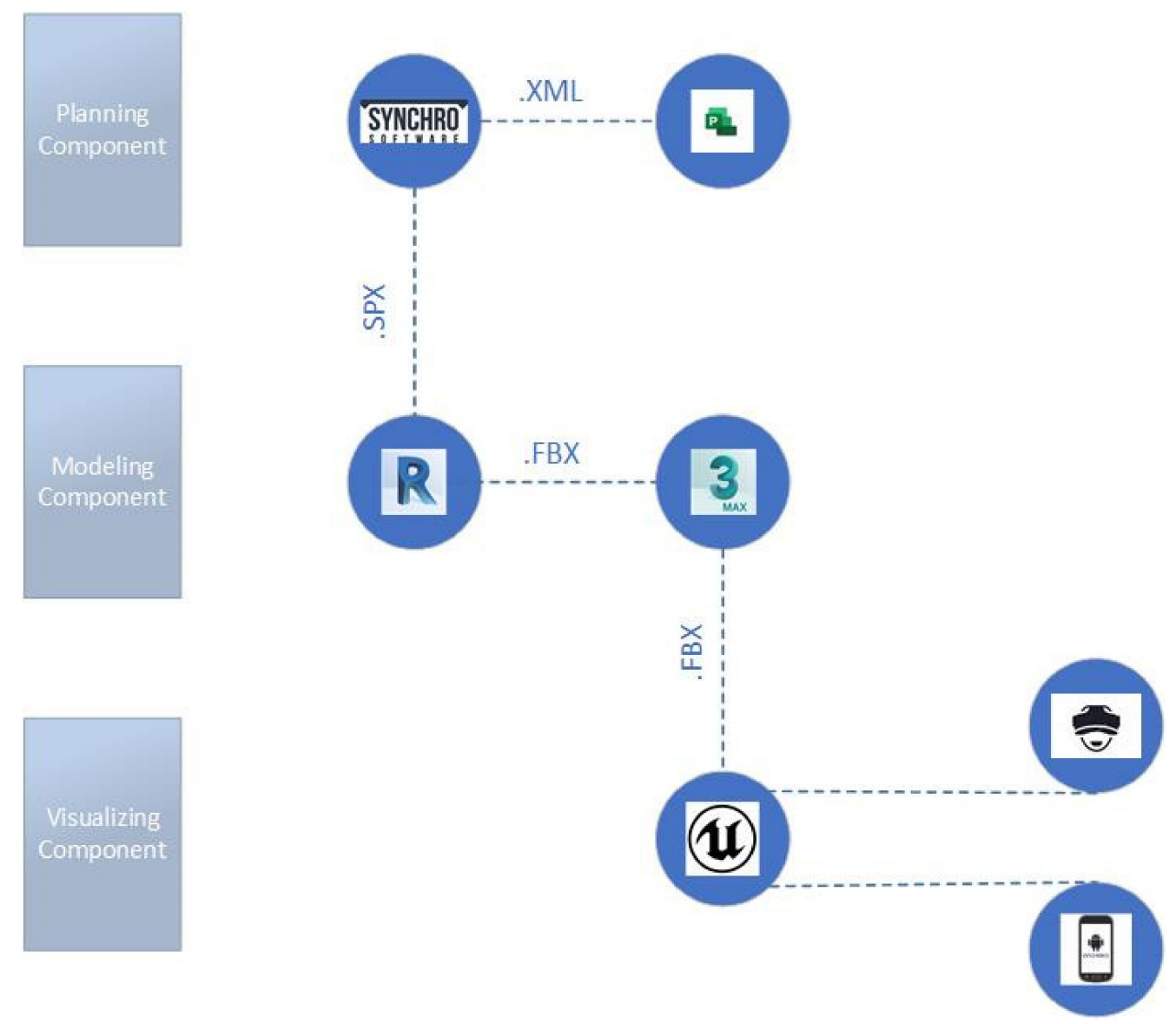

Figure 4. Simulation module and file exchange within the software.

\section{Research Results and Findings}

After completion of the simulation, trials were conducted to evaluate its potential in improving communication among different safety experts and the on-site workers. The participants of this case study were chosen to include a variety of native languages; for example, the project manager spoke English, the H\&S manager, Arabic, the safety inspector, Urdu/Hindi and the construction site worker, Pushto/Punjabi.

In the simulation, 2D plans and prior experience of the safety personnel were used to create risk assessment reports and the calculated risks were communicated to the construction workers on-site. The $4 \mathrm{D}$ simulations were used by the personnel at all levels to detect all possible safety threats and accordingly propose sound safety decisions to avert risks and minimize safety challenges. This section discusses the evaluation scheme used to validate the VR-based $4 \mathrm{D}$ simulation designed to mitigate the safety threats arising from the lack of communication within the multilingual construction industry of the UAE. The evaluation process included concept and prototype evaluation and effectiveness evaluation to evaluate the strengths and challenges of the safety simulation (Figure 5). 


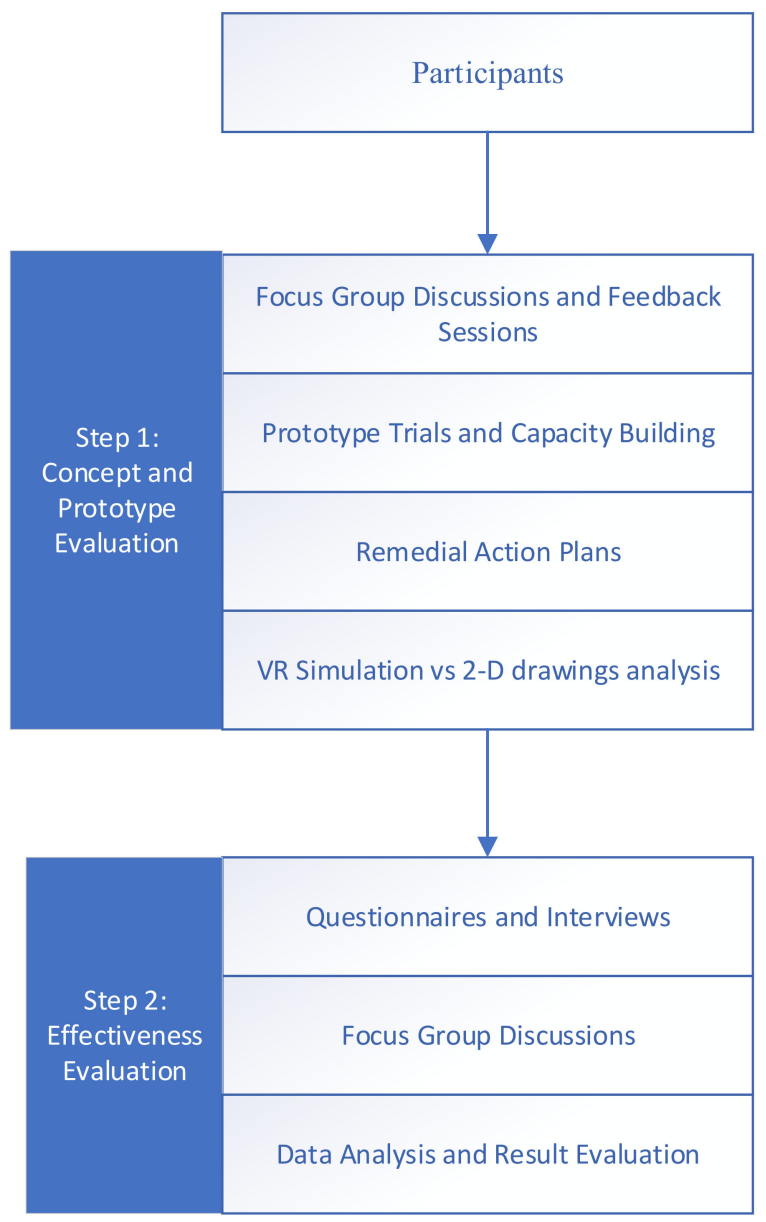

Figure 5. Evaluation scheme.

\subsection{Stage 1: Concept and Prototype Evaluation}

First, the concept of the 4D VR simulation for safety decision-making was proposed to the stakeholders. Initially, a project manager and two project safety experts were included in the focus group to discuss the simulation concept and to determine if this safety exercise will improve communication and knowledge exchange within the three levels of the hierarchy structure. Participants were made aware of the digital tools (4D BIM and VR) being used globally to improve different aspects of construction. For this purpose, they were shown Synchro-based 4D simulation (Figure 6). Any variation in the timeline, which occurred because of the schedule change, was also updated for simulation. This preliminary evaluation of the concept was a subjective study, which comprised a primarily unstructured feedback session. The participants were conveyed the concept of the VR-based simulation to improve the flow of information regarding safety and to visualize the activities related to project execution. Accordingly, the participants of this focus group also engaged in discussions and provided feedback about the $4 \mathrm{D}$ simulation. The safety experts within the focus group agreed that the VR-based simulation helped make safety-related decisions, and the project manager confirmed that the simulation will be helpful in the overall execution of the building as they can anticipate the safety execution problems (clashes, safety threats, and design) and make decisions proactively ensuring the smooth execution of the project. Moreover, they considered this an engaging exercise and expected it to strengthen the capacity building of the focus group and improve the information flow hampered by the language differences between them and on-site workers. 


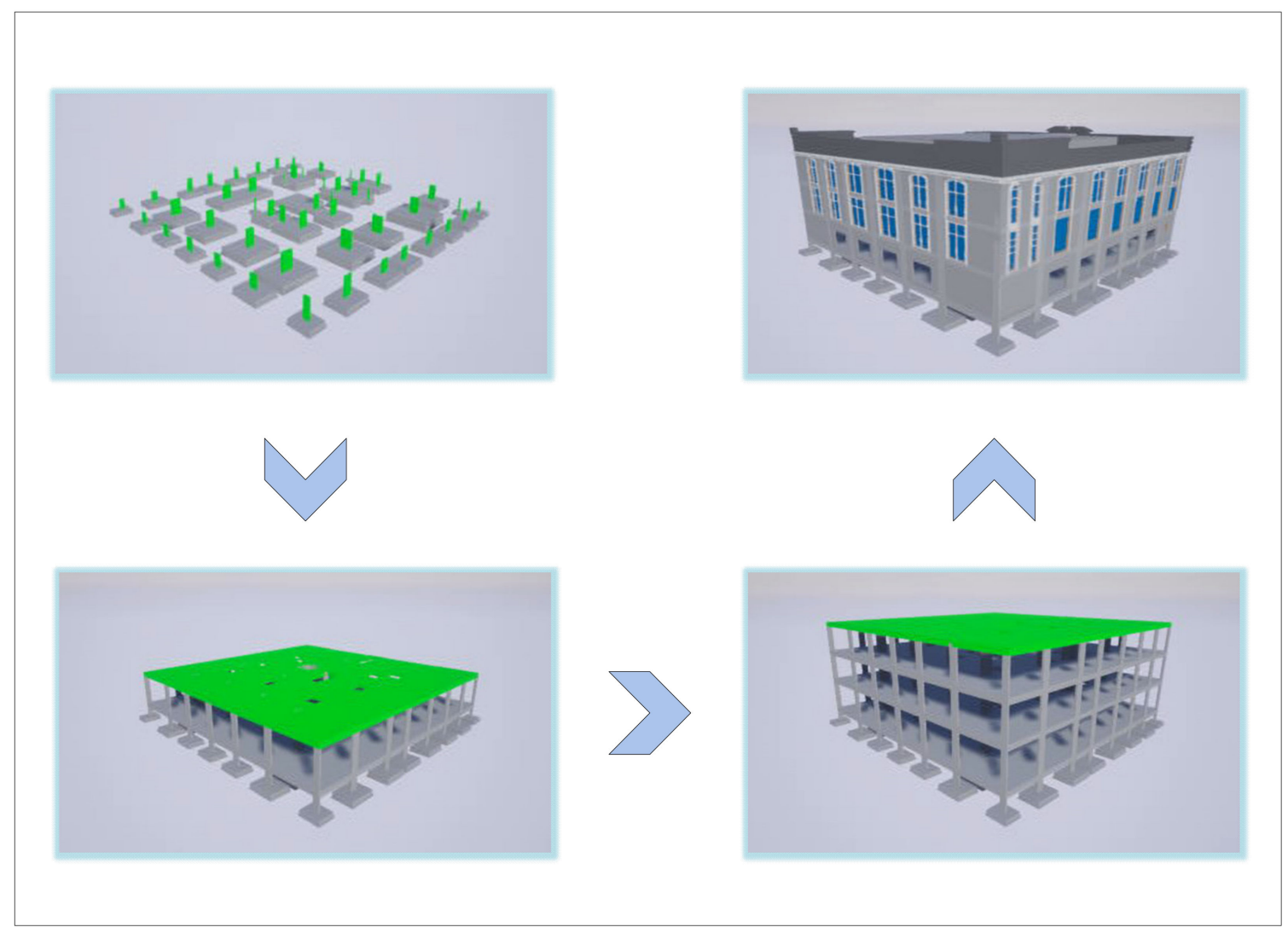

Figure 6. Synchro simulation.

In the next phase, after developing the simulation, it was evaluated through a risk assessment exercise. The focus group described earlier and two on-site masonry construction workers participated in this exercise. The initial interface of the simulation is shown in Figure 7. The simulation also included a timeline (Figure $7 \mathrm{~b}$ ) that indicated a live schedule that helped the viewer visualize the complete sequence of the project. The timeline helped the user to find the exact date when an activity will start or finish and hence to make proactive safety decisions accordingly. The project manager initially explored the $4 \mathrm{D}$-based walkthrough through VR headsets; provided useful comments about the progression of the project and made recommendations regarding certain activities to be conducted to avert potential safety threats. During this process, construction experts visualized the display on the projector.

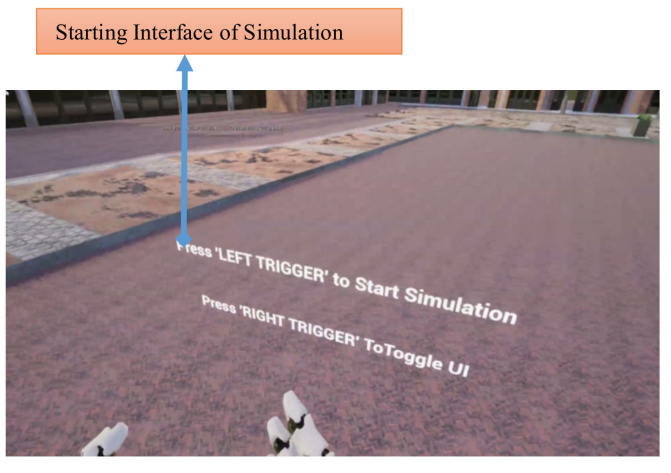

(a)

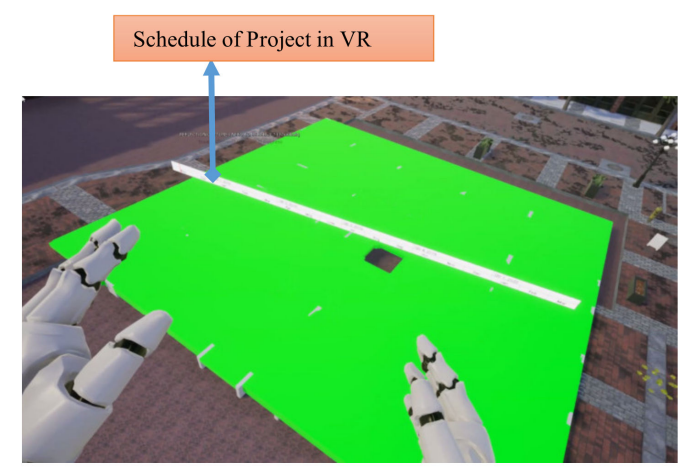

(b)

Figure 7. Simulation set up and process: (a) Start screen; (b) Live scheduled update of the project. 
Then, the H\&S manager performed the same exercise and interacted with the VR facility. With the help of a VR walkthrough, he detected safety lapses in the project. According to Navon et al. [105] fall from heights is the main cause for fatalities and injuries in construction projects, hence the scope of this research helped construction experts devise strategies to help avoid fall incidents. These lapses were communicated with the members of the meeting, and on-site workers also experienced VR simulation to understand the gravity of safety threats. Once both the H\&S experts (manager and inspector), explored the VR walkthrough, they were tasked with making a probability impact matrix (Table 1) for prominent falling hazards. Table 1 mentions the aforementioned safety threats. The likelihood (Lik) and severity (Sev) of probable safety threats were recorded, and accordingly, remedial actions were devised. The likelihood is the chance of a safety hazard that may or may not occur, whereas severity is the extent to which a hazard can cause harm [106]. By devising remedies, the severity of a safety threat can be reduced. The NCEMA risk assessment matrix [13] (Table 2), which was used by the contractors, presents the likelihood and severity for various safety risk categories.

This safety exercise also gave the on-site workers a chance to imbibe hazard mitigation strategies to successfully avoid any critical situation that they may face during execution. Simultaneously, for the safety lapses, remedial action plans were devised by the safety experts and conveyed to the workers to avoid injury. These safety planning sessions lasted 30-50 min (depending on the complexity of hazards and project information), for two participants (masonry workers) to fully grasp the safety scenarios and improve their capacity building. The complete knowledge exchange process is depicted in Figure 8. Considering the language differences between the participants, care was taken to ensure that everyone fully comprehended the safety lapse by experiencing the VR simulation. Similarly, the safety planning exercise was then repeated with teams from other disciplines to design risk assessment plans to mitigate threats and leverage the maximum advantage of the $4 \mathrm{D}$ simulation. The safety animation was also available to the safety supervisor working on-site with construction workers through mobile devices.

Table 1. Probability impact matrix.

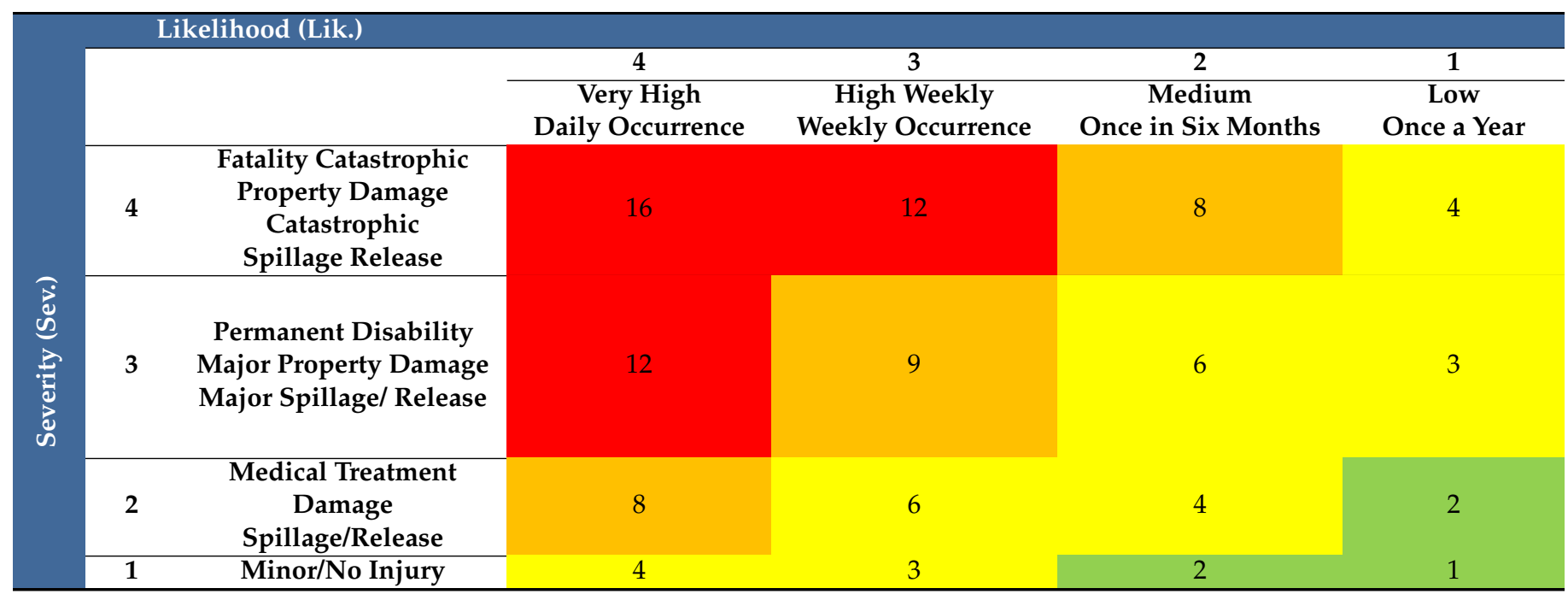


Table 2. NCEMA risk assessment matrix for likelihood and severity for safety risk categories.

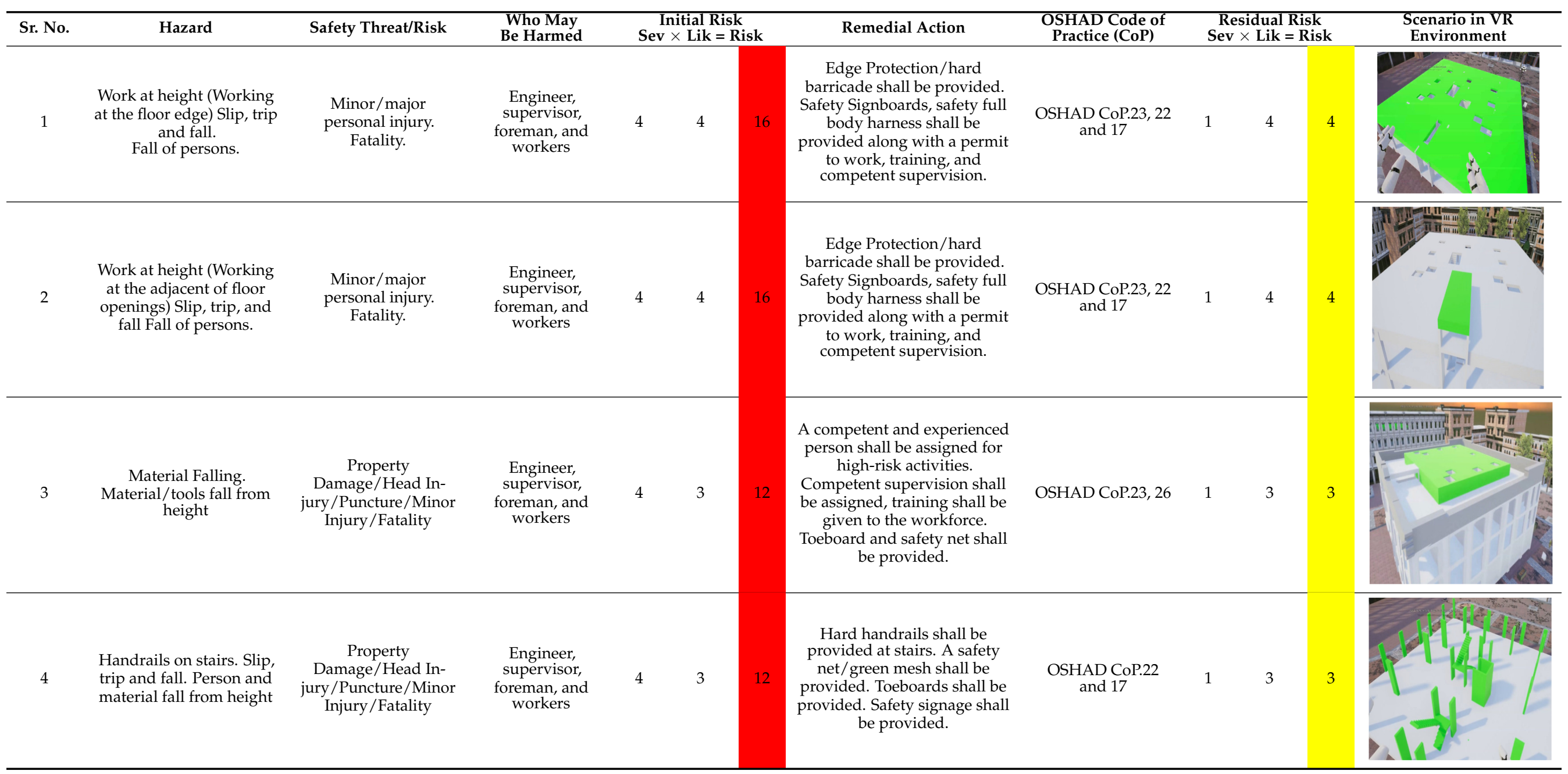


Table 2. Cont

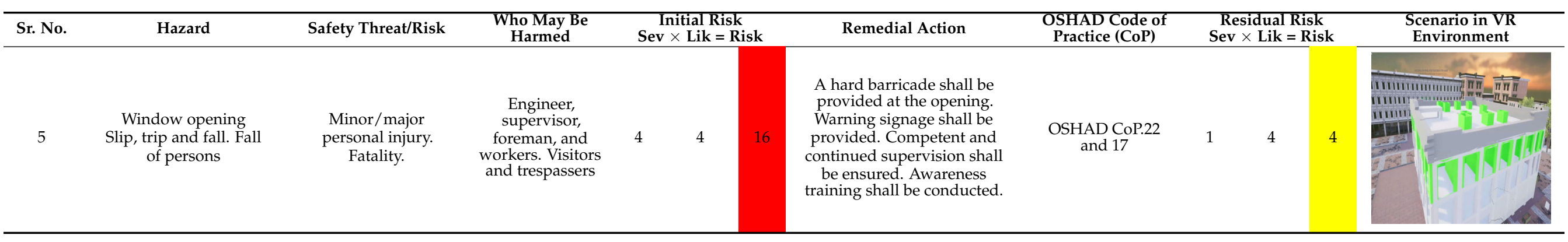




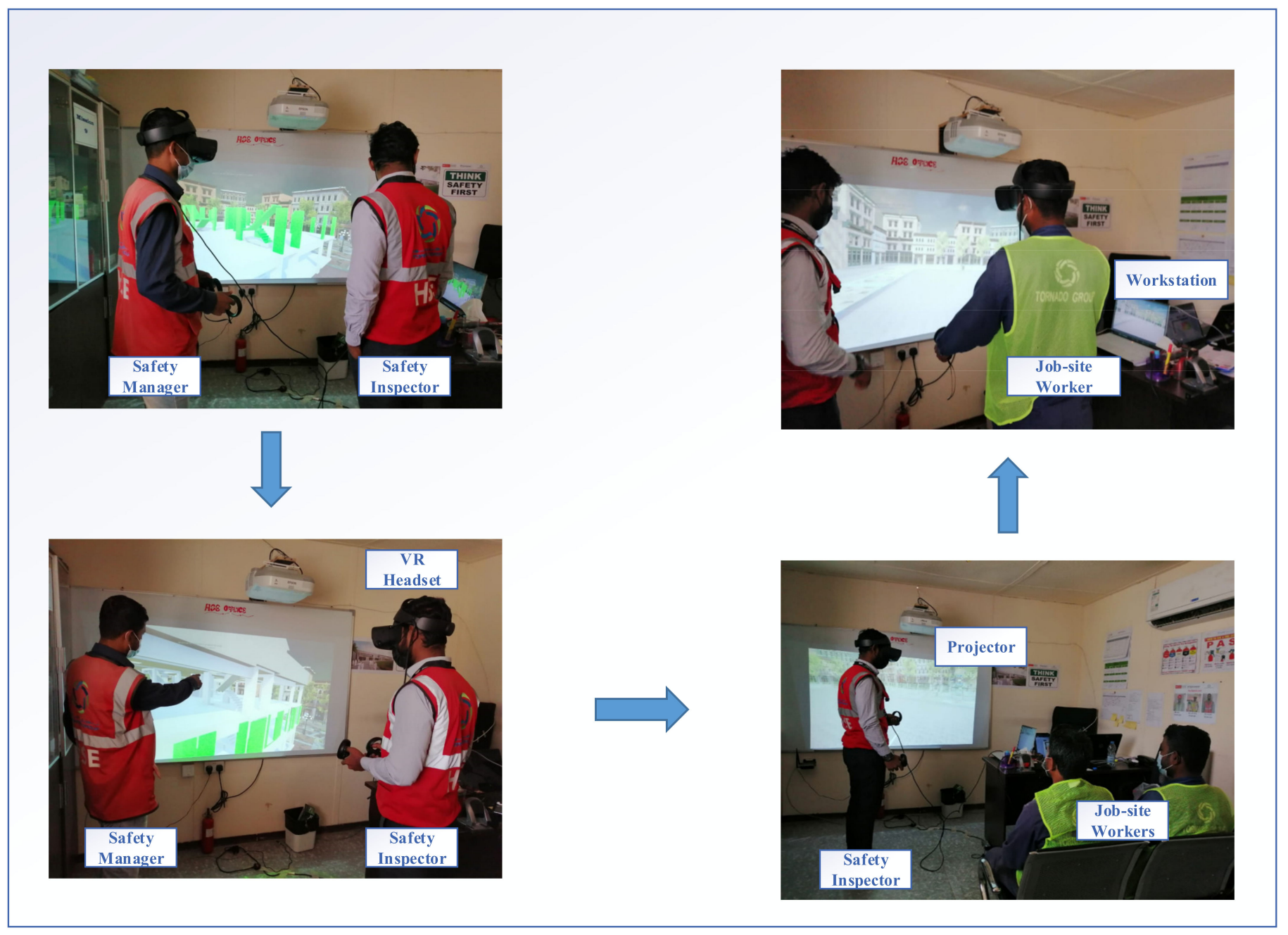

Figure 8. Knowledge exchange between participants.

\subsection{Stage 2: Effectiveness Evaluation}

Before starting the simulation, participants were instructed about the use of the VR equipment and the touch controllers to perform walkthroughs during the immersion. The participants mentioned that these instructions were "clear." They described this experiential experience as "thorough", "immersive", and "easy to use". A 5-point Likert scale questionnaire (1-Useless, 2-Ineffective, 3-Normal, 4-Effective, and 5-Highly Effective) was used to evaluate the effectiveness of the VR technology from the viewpoints of clarity of instructions, ease of use, interactivity with the virtual environment, the comfort of using a smart device, and engagement (Figure 9). The participants found the safety simulation "engaging". Initially, the workers on the site were hesitant to try it, but they quickly adapted to the technology and understood the safety instructions provided by their supervisor during the exercise. The participants also appreciated the graphics of the module and described it as a "near-real experience". The participants appreciated the simulation and showed interest in implementing the digital tools (BIM and VR) to ensure the easy flow of information and instructions.

In the next stage of evaluation, a mixed-method research technique comprising questionnaires and interviews was used. The parameters evaluated the potential of the technology in comparison with 2D drawings to improve safety-related capacity building, hazard detection ability, accessibility to safety information, and flow of communication about instructions/safety threats. For the questionnaire, a 5-point Likert scale was used (1-Much 
Worse, 2-Somewhat Worse, 3-Stayed the Same, 4-Somewhat Better, and 5-Much Better). This exercise lasted for $30 \mathrm{~min}$. Table 3 lists the questionnaire and interview results in brief.

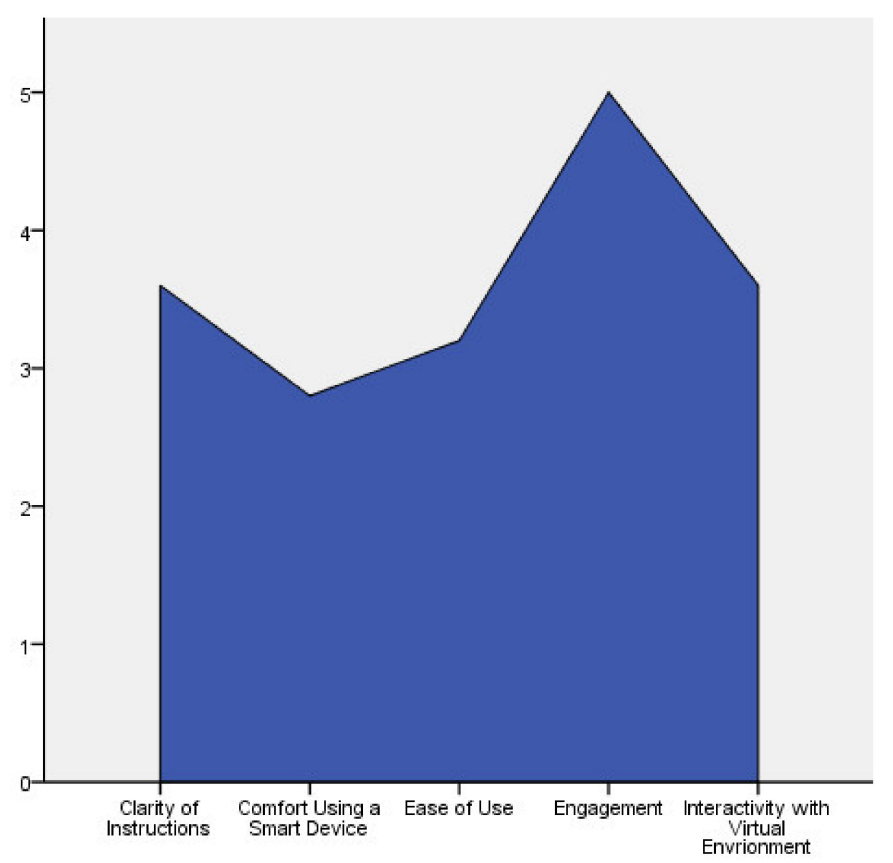

Figure 9. Effectiveness of the VR technology.

Table 3. Summary of the mixed-method survey.

\begin{tabular}{|c|c|c|c|}
\hline Sr. No. & Issues & Mean Score & Results \\
\hline 1 & $\begin{array}{l}\text { Increase safety-related } \\
\text { capacity building }\end{array}$ & 4.6 & $\begin{array}{l}\text { Very Helpful } \\
\text { A high score depicts that VR-based tools are more } \\
\text { helpful in safety training than traditional methods of } \\
\text { safety learning }\end{array}$ \\
\hline 2 & $\begin{array}{l}\text { Improve hazard } \\
\text { detection ability }\end{array}$ & 4.7 & $\begin{array}{l}\text { Very Helpful } \\
\text { More hazards were identified through technology } \\
\text { than 2-D drawings and method statements, making } \\
\text { these tools more effective }\end{array}$ \\
\hline 3 & $\begin{array}{l}\text { Improve accessibility to } \\
\text { safety information }\end{array}$ & 4.0 & $\begin{array}{l}\text { Helpful } \\
\text { VR technology improves the safety decision making } \\
\text { and trains the workers, only if the workers and } \\
\text { managers work together to resolve issues and } \\
\text { communicate the safety information }\end{array}$ \\
\hline 4 & $\begin{array}{l}\text { Improve the flow of } \\
\text { communication regarding } \\
\text { instructions / safety threats }\end{array}$ & 4.2 & $\begin{array}{l}\text { Helpful } \\
\text { Although the information exchange increases through } \\
\text { the VR sessions, training each worker through VR } \\
\text { immersion is not effective in terms of managing } \\
\text { time resource }\end{array}$ \\
\hline 5 & $\begin{array}{l}\text { Improve overall safety } \\
\text { planning process }\end{array}$ & 4.0 & $\begin{array}{l}\text { Helpful } \\
\text { Although digital safety planning increases the safety } \\
\text { planning process, the time is taken to model the } \\
\text { project and train the workers makes it } \\
\text { a time-consuming job. }\end{array}$ \\
\hline
\end{tabular}

The simulation results of the participants indicated that they missed safety threats owing to a lack of interaction between engineering drawings. These inadequacies were ignored in the initial safety planning of the project, but after the safety simulation was 
conducted, remedial actions were notified to the on-site crew. The safety and execution personnel on-site experienced the safety threats with the help of VR. The results indicated that the 4D BIM-based VR simulation performed much better during safety planning than only the experience of safety experts and engineering drawings.

\section{Discussion}

Based on the data collected during the case study trials, the potential benefits and limitations of the VR technology were identified. The advantages of the 4D BIM-based VR simulation are as follows:

The 4D BIM-based VR simulation helped safety personnel develop a systematic safety plan, which was previously dependent on the prior safety knowledge and interpretation of 2D drawings. The contractor company did not have any digitalized tools or framework to implement safety practices, making it difficult to predetermine the safety threats of the project. Using digital tools, the safety experts along with the project manager discussed a stepwise timeline and identified all safety threats that may cause any variation in the schedule or causalities on-site. This also helped them devise a formal plan consisting of better work sequencing, safety inspection, and education and training of the workers.

A digitized framework is essential for minimizing safety threats in the UAE. The proposed $4 \mathrm{D}$ simulation helped improve the flow of information and knowledge from the decision-making hierarchy to the on-site labour working on the project. Research conducted by the immersion and walkthrough presentation benefited not only the decision-makers but also on-site workers by enhancing their capacity building concerning construction safety and hazard detection abilities.

Previously, in the absence of digital tools and technology, it was difficult for the safety experts to communicate potential threats to on-site workers since the knowledge and instructions were based on tacit safety experience. By incorporating digital mechanisms, information regarding activities can be passed to the workers on-site, thereby enabling smooth execution.

Most of the active safety training involves scenario-based learning, where certain scenes cover only a few safety threats and do not provide a holistic view of all the different types of safety lapses of which a worker must be aware. The 4D BIM-based VR safety training allows the contractor to prepare, predict, and devise remedies for all the safety threats that may occur at any stage and hamper on-site construction. The VR-based learning may help the worker visualize the exact risk they may face without actually risking their lives, and they can learn the exact environment of the construction project.

Several issues were also noted. These challenges should be addressed in future work:

In the simulation exercise, both fiscal and human resources were used. If the client does not mandate the use of digital tools for safety planning and does not incentivize the contractor to implement them, it will be difficult to incorporate the technology into conventional safety planning.

The level of detail (LOD) for the entire simulation was not consistent. For example, LOD 300 was applied for the concrete floors and walls, whereas LOD 250 was applied for the other building components such as the ceiling and architectural façade walls. This difference in LOD hampers the review of the entire building by the safety experts and project manager, and some crucial aspects of safety planning may be overlooked for a component with lower LOD.

The use of the 4D BIM-based VR module may be suitable for one type of project and may be relevant for projects with similar parameters and Revit families and components. However, the exercise will not be equally effective if the buildings have entirely different components and scope. Modelling and developing 4D simulation in a gaming engine for a new project will be time-consuming. Hence, a repeatable workflow is recommended, and this will be considered in future work.

The safety simulation helped the experts devise a systematic digital safety plan and devise remedial plans for potential safety threats. The experts who are not aware or 
experienced in using digital tools such as 4D BIM, VR, or 3D visualizing software, may find it slightly difficult to adapt to these new technologies and incorporate them into the conventional construction processes.

Overall, the focus group of this study experienced the benefits of the proposed experiential safety simulation and showed interest in pursuing digital mechanisms not only for safety planning but also for other aspects of construction.

Thus, this case study helped the stakeholders of the project to use 4D BIM and VR for digital safety planning. However, producing BIM-enabled VR simulations at various stages of the project to represent up to date site information is a time-consuming job and a tedious process.

Considering this challenge, in future work, a robust and repeatable framework that requires only minimal necessary changes as the input and can adapt with the specifications will be explored from the perspective of generating VR-based $4 \mathrm{D}$ simulations of the project in less time and with low economic costs.

\section{Conclusions}

In this study, a VR based 4-D simulation was proposed as an alternative to traditional construction safety practices in a multilingual construction environment. A case study of a real-time project in the UAE was conducted for improving construction safety. The case study involved the development of 4D BIM models and VR simulation to improve safety planning by visualizing hazards and training workers to take proactive measures to avoid injuries. The safety exercise was initiated with hazard-identification-based risk assessment, where the project team participated in identifying possible safety lapses. It was ensured that these threats were communicated effectively to the workers on-site without a language barrier to allow them to act proactively during job-site activities. The project team was given a briefing on using the VR equipment in advance. The on-site workers have explained the safety remedial plan to be followed to avert any on-site risk. Subsequently, the design evaluation scheme was implemented to evaluate the effectiveness of the simulation. A Likert scale questionnaire was used that indicated that the VR environment encouraged the site crew to participate in proactive safety planning, was easy to use and created a real-life scenario without actually being on the site. Then, an analysis was conducted using a mixed methodology involving specific questions about the effectiveness of VR simulation, especially in comparison with the traditional method of safety planning (the 2D drawings and method statement). All the participants agreed on the benefits of using VR-based tools to help detect safety problems and take remedial actions. However, although safety visualization is beneficial, considering the exploratory nature of the digital tools, this study does not disregard the safety-related expertise of the OHS personnel on and off-site. Moreover, this case study should be expanded and implemented for other projects as well to improve the deficiencies in the simulation.

This study concludes that a combination of digital tools such as 4D BIM and VR can help reduce job-site safety threats and increase knowledge sharing by predetermining safety hazards and training on-site workers. This will ultimately reduce the language barriers within a multilingual environment and lead to an overall improvement of the H\&S environment of the construction industry of the region.

The UAE has already implemented BIM and is a practitioner of good safety practices. More work is necessary to incorporate digital tools to digitize safety-planning practices. Researchers should develop tools and plugins that incorporate local safety regulations to improve safety. Implementation steps should be taken at all levels of stakeholders to support these initiatives. Joint ventures between government municipalities, universities, and private entities can drive advances in digital mechanisms to improve construction safety.

Author Contributions: Conceptualization, M.T.S.; methodology, M.A.; software, M.A.; validation, M.A.; formal analysis, M.A.; investigation, M.A.; resources, M.T.S.; data curation, M.A.; writingoriginal draft preparation, M.A.; writing—review and editing, M.T.S. and M.A.; visualization, M.A.; 
supervision, M.T.S.; project administration, M.T.S.; funding acquisition, M.T.S. Both authors have read and agreed to the published version of the manuscript.

Funding: This research received no external funding.

Institutional Review Board Statement: Ethical review and approval were waived for this study.

Informed Consent Statement: Informed consent was obtained from all subjects involved in the study.

Data Availability Statement: Not applicable.

Conflicts of Interest: The authors declare no conflict of interest.

\section{References}

1. El-Sayegh, S.; Ahmad, I.; Aljanabi, M.; Herzallah, R.; Metry, S.; El-Ashwal, O. Construction Disputes in the UAE: Causes and Resolution Methods. Buildings 2020, 10, 171. [CrossRef]

2. Mehran, D. Exploring the Adoption of BIM in the UAE Construction Industry for AEC Firms. Procedia Eng. 2016, 145, 1110-1118. [CrossRef]

3. In Proceedings of the Expo Home I Connecting Minds, Creating the Future I Expo 2020 Dubai, Dubai, United Arab Emirates, 1 October 2021-31 March 2022; Volume 2020. Available online: https:/ /www.expo2020dubai.com/ (accessed on 29 March 2021).

4. Statista. Global Construction Expenditure Share Forecast. 2020. Available online: https://www.statista.com/statistics/561896 / construction-spending-share-forecast-worldwide-by-region/ (accessed on 30 March 2021).

5. El-Sayegh, S.M. Risk Assessment and Allocation in the UAE Construction Industry. Int. J. Proj. Manag. 2008, 26, 431-438. [CrossRef]

6. Shafiq, M.T.; Afzal, M. Improving Construction Job Site Safety with Building Information Models: Opportunities and Barriers; Toledo Santos, E., Scheer, S., Eds.; Springer: Cham, Switzerland, 2021. [CrossRef]

7. Grivna, M.; Aw, T.C.; El-Sadig, M.; Loney, T.; Sharif, A.A.; Thomsen, J.; Mauzi, M.; Abu-Zidan, F.M. The Legal Framework and Initiatives for Promoting Safety in the United Arab Emirates. Int. J. Inj. Control Saf. Promot. 2012, 19, 278-289. [CrossRef] [PubMed]

8. Demography, Migration and the Labour Market in the UAE. Explanatory Note. 2021. Available online: https://cadmus.eui.eu/ bitstream/handle/1814/36375/GLMM_ExpNote_07_2015.pdf?sequence=1\&isAllowed=y (accessed on 30 March 2021).

9. Tong, Q.; Al Awad, M. Diversity and wage inequaliy in the UAE labor market. J. Econ. Int. Bus. Manag. 2014, 2, 59-72. Available online: http:/ / www.sciencewebpublishing.net/jeibm/archive/2014/3/pdf/Tong\%20and\%20Al\%20Awad.pdf (accessed on 30 March 2021).

10. En Migrant Workers in the United Arab Emirates. Wikipedia. 2021. Available online: https://en.wikipedia.org/wiki/Migrant_ workers_in_the_United_Arab_Emirates (accessed on 30 March 2021).

11. Azhar, S.; Behringer, A. A BIM-Based Approach for Communicating and Implementing a Construction Site Safety Plan. In Proceedings of the 49th ASC Annual International Conference 2013, San Luis Obispo, CA, USA, 10-13 April 2013.

12. Zekri, M.K.S. Construction Safety and Health Performance in Dubai. Ph.D. Thesis, Heriot Watt University, Edinburgh, UK, 2013.

13. The Supreme Council for National Security. UAE Occupational Health and Safety Management System (OHSMS). National Standard; The Supreme Council for National Security: Abu Dhabi, United Arab Emirates, 2021. Available online: https://www.ncema.gov. ae/dassets/download/1e00f2bc/NCEMA\%206000\%20English.pdf.aspx (accessed on 30 March 2021).

14. Zhou, Z.; Irizarry, J.; Li, Q. Applying Advanced Technology to Improve Safety Management in the Construction Industry: A Literature Review. Constr. Manag. Econ. 2013, 31, 606-622. [CrossRef]

15. Melzner, J.; Zhang, S.; Teizer, J.; Bargstädt, H.-J. A Case Study on Automated Safety Compliance Checking to Assist Fall Protection Design and Planning in Building Information Models. Constr. Manag. Econ. 2013, 31, 661-674. [CrossRef]

16. Ringen, K.; Seegal, J.; Englund, A. Safety and health in the construction industry. Annu. Rev. Public Health 1995, 301, 165-188. [CrossRef]

17. Martins, S.S.; Evangelista, A.C.J.; Hammad, A.W.A.; Tam, V.W.Y.; Haddad, A. Evaluation of 4D BIM Tools Applicability in Construction Planning Efficiency. Int. J. Constr. Manag. 2020, 1-14. [CrossRef]

18. Boton, C.; Kubicki, S.; Halin, G. The Challenge of Level of Development in 4D/BIM Simulation Across AEC Project Lifecyle. A Case Study. Procedia Eng. 2015, 123, 59-67. [CrossRef]

19. Yang, B.; Zhang, B.; Wu, J.; Liu, B.; Wang, Z. A BIM-Based Quantity Calculation Framework for Frame-Shear Wall Structure. Struct. Eng. Int. 2019, 29, 282-291. [CrossRef]

20. Riaz, Z.; Arslan, M.; Kiani, A.K.; Azhar, S. CoSMoS: A BIM and Wireless Sensor Based Integrated Solution for Worker Safety in Confined Spaces. Autom. Constr. 2014, 45, 96-106. [CrossRef]

21. Taiebat, M. Tuning Up BIM for Safety Analysis Proposing Modeling Logics for Application of BIM in DfS. Ph.D. Thesis, Virginia Polytechnic Institute and State University, Blacksburg, VA, USA, 2011.

22. Lopez del Puerto, C.; Clevenger, C. Enhancing Safety Throughout Construction Using BIM/VDC. In Proceedings of the Eco Build Conference-ECOBuild 2010 BIM Academic Forum, Washington, DC, USA, 7 December 2010. 
23. Jung, Y.; Joo, M. Building Information Modelling (BIM) Framework for Practical Implementation. Autom. Constr. 2011, 20, 126-133. [CrossRef]

24. Charef, R.; Alaka, H.; Emmitt, S. Beyond the Third Dimension of BIM: A Systematic Review of Literature and Assessment of Professional Views. J. Build. Eng. 2018, 19, 242-257. [CrossRef]

25. Boton, C. Supporting Constructability Analysis Meetings with Immersive Virtual Reality-Based Collaborative BIM 4-D Simulation. Autom. Constr. 2018, 96, 1-15. [CrossRef]

26. Davila Delgado, J.M.; Oyedele, L.; Beach, T.; Demian, P. Augmented and Virtual Reality in Construction: Drivers and Limitations for Industry Adoption. J. Constr. Eng. Manag. 2020, 146, 04020079. [CrossRef]

27. Goulding, J.; Nadim, W.; Petridis, P.; Alshawi, M. Construction Industry Offsite Production: A Virtual Reality Interactive Training Environment Prototype. Adv. Eng. Inform. 2012, 26, 103-116. [CrossRef]

28. Clevenger, C.; Lopez del Puerto, C. Using 3D visualization to train Hispanic construction workers. In Proceedings of the 47th ASC Annual International Conference, Omaha, NE, USA, 6-9 April 2011.

29. Zhang, L.; Wu, X.; Skibniewski, M.J.; Zhong, J.; Lu, Y. Bayesian-Network-Based Safety Risk Analysis in Construction Projects. Reliab. Eng. Syst. Saf. 2014, 131, 29-39. [CrossRef]

30. Guo, H.; Yu, Y.; Skitmore, M. Visualization Technology-Based Construction Safety Management: A Review. Autom. Constr. 2017, 73, 135-144. [CrossRef]

31. Carter, G.; Smith, S.D. Safety Hazard Identification on Construction Projects. J. Constr. Eng. Manag. 2006, 132, 197-205. [CrossRef]

32. Zhang, S.; Teizer, J.; Lee, J.; Eastman, C.M.; Venugopal, M. Building Information Modeling (BIM) and Safety: Automatic Safety Checking of Construction Models and Schedules. Autom. Constr. 2013, 29, 183-195. [CrossRef]

33. Ganah, A.A.; John, G.A. BIM and Project Planning Integration for On-Site Safety Induction. J. Eng. Des. Technol. 2017, 15, 341-354. [CrossRef]

34. Zou, P.X.; Zhang, G. Comparative Study on the Perception of Construction Safety Risks in China and Australia. J. Constr. Eng. Manag. 2009, 135, 620-627. [CrossRef]

35. Okorie, V.N.; Musonda, I. An Investigation on Supervisor's Ability and Competency to Conduct Construction Site Health and Safety Induction Training in Nigeria. Int. J. Constr. Manag. 2020, 20, 357-366. [CrossRef]

36. Loosemore, M.; Malouf, N. Safety Training and Positive Safety Attitude Formation in the Australian Construction Industry. Saf. Sci. 2019, 113, 233-243. [CrossRef]

37. Azhar, S. Role of Visualization Technologies in Safety Planning and Management at Construction Jobsites. Procedia Eng. 2017, 171, 215-226. [CrossRef]

38. Zhang, S.; Sulankivi, K.; Kiviniemi, M.; Romo, I.; Eastman, C.M.; Teizer, J. BIM-Based Fall Hazard Identification and Prevention in Construction Safety Planning. Saf. Sci. 2015, 72, 31-45. [CrossRef]

39. Choe, S.; Leite, F. Temporal and Spatial Information Integration for Construction Safety Planning. J. Comput. Civ. Eng. 2015, 483-490. [CrossRef]

40. Haslam, R.A.; Hide, S.A.; Gibb, A.G.; Gyi, D.E.; Pavitt, T.; Atkinson, S.; Duff, A.R. Contributing Factors in Construction Accidents. Appl. Ergon. 2005, 36, 401-415. [CrossRef]

41. Irizarry, J.; Gheisari, M.; Walker, B.N. Usability Assessment of Drone Technology as Safety Inspection Tools. J. Inf. Technol. Constr. 2012, 17, 194-212.

42. Park, C.S.; Kim, H.J. A Framework for Construction Safety Management and Visualization System. Autom. Constr. 2013, 33, 95-103. [CrossRef]

43. Park, J.; Kim, K.; Cho, Y.K. Framework of Automated Construction-Safety Monitoring Using Cloud-Enabled BIM and BLE Mobile Tracking Sensors. J. Constr. Eng. Manag. 2017, 143, 05016019. [CrossRef]

44. Lin, K.Y.; Tsai, M.H.; Gatti, U.C.; Je-Chian Lin, J.; Lee, C.H.; Kang, S.C. A User-Centered Information and Communication Technology (ICT) Tool to Improve Safety Inspections. Autom. Constr. 2014, 48, 53-63. [CrossRef]

45. Hallowell, M.R. Safety-Knowledge Management in American Construction Organizations. J. Manag. Eng. 2012, $28,203-211$. [CrossRef]

46. Golparvar-Fard, M.; Peña-Mora, F.; Arboleda, C.A.; Lee, S. Visualization of Construction Progress Monitoring with 4-D Simulation Model Overlaid on Time-Lapsed Photographs. J. Comput. Civ. Eng. 2009, 23, 391-404. [CrossRef]

47. Gao, Y.; Gonzalez, V.A.; Yiu, T.W. The Effectiveness of Traditional Tools and Computer-Aided Technologies for Health and Safety Training in the Construction Sector: A Systematic Review. Comput. Educ. 2019, 138, 101-115. [CrossRef]

48. Li, H.; Chan, G.; Skitmore, M. Visualizing Safety Assessment by Integrating the Use of Game Technology. Autom. Constr. 2012, 22, 498-505. [CrossRef]

49. Guo, H.; Li, H.; Chan, G.; Skitmore, M. Using Game Technologies to Improve the Safety of Construction Plant Operations. Accid. Anal. Prev. 2012, 48, 204-213. [CrossRef]

50. Harfield, T.; Panko, M.; Davies, K.; Kenley, R. Toward a Learning-Styles Profile of Construction Students: Results from New Zealand. Int. J. Constr. Educ. Res. 2007, 3, 143-158. [CrossRef]

51. Martínez-Rojas, M.; Martín Antolín, R.; Salguero-Caparrós, F.; Rubio-Romero, J.C. Management of Construction Safety and Health Plans Based on Automated Content Analysis. Autom. Constr. 2020, 120, 103362. [CrossRef] [PubMed] 
52. Alsamadani, R.; Hallowell, M.R.; Javernick-Will, A.; Cabello, J. Relationships among Language Proficiency, Communication Patterns, and Safety Performance in Small Work Crews in the United States. J. Constr. Eng. Manag. 2013, 139, 1125-1134. [CrossRef]

53. Marefat, A.; Toosi, H.; Mahmoudi Hasankhanlo, R. A BIM Approach for Construction Safety: Applications, Barriers and Solutions. Eng. Constr. Archit. Manag. 2019, 26, 1855-1877. [CrossRef]

54. Mroszczyk, J.W. Improving Construction Safety: A Team Effort. Prof. Saf. 2015, 60, 55-68.

55. Demirkesen, S.; Arditi, D. Construction Safety Personnel's Perceptions of Safety Training Practices. Int. J. Proj. Manag. 2015, 33, 1160-1169. [CrossRef]

56. Salleh, N.A.; Mohd Nordin, N.; Abdul Rashid, A.K. The Language Problem Issue Among Foreign Workers in the Malaysian Construction Industry. Int. J. Bus. Soc. Sci. 2012, 3, 97-99.

57. Siniavskaia, N. What States Are Most Reliant on Immigrant Construction Workers I Eye on Housing I National Association of Home Builders Discusses Economics and Housing Policy. 2021. Available online: https://eyeonhousing.org/2020/0 3/what-states-are-most-reliant-on-immigrant-construction-workers /\#: \{\}:text=Foreign\%2Dborn \%20workers $\% 20$ now $\% 20$ account,labor\%20is\%20even\%20more\%20pronounced.\&text=The \%20foreign $\% 2$ Dborn $\% 20$ share $\% 20$ is, $\% 2$ C $\% 20$ between $\% 2036$ \%20and\%2037\%25 \T1 \textgreater\{\} (accessed on 6 April 2021).

58. Dai, J.; Goodrum, P.M. Differences in Perspectives Regarding Labor Productivity Between Spanish- and English-Speaking Craft Workers. J. Constr. Eng. Manag. 2011, 137, 689-697. [CrossRef]

59. Lim, E.; Alum, J. Construction Productivity: Issues Encountered by Contractors in Singapore. Int. J. Proj. Manag. 1995, 13, 51-58. [CrossRef]

60. Han, S.H.; Park, S.H.; Jin, E.J.; Kim, H.; Seong, Y.K. Critical Issues and Possible Solutions for Motivating Foreign Construction Workers. J. Manag. Eng. 2008, 24, 217-226. [CrossRef]

61. Bust, P.D.; Gibb, A.G.F.; Pink, S. Managing Construction Health and Safety: Migrant Workers and Communicating Safety Messages. Saf. Sci. 2008, 46, 585-602. [CrossRef]

62. Santoso, D.S. The Construction Site as a Multicultural Workplace: A Perspective of Minority Migrant Workers in Brunei. Constr. Manag. Econ. 2009, 27, 529-537. [CrossRef]

63. Manuele, F.A. Prevention Through Design (PtD): History and Future. J. Saf. Res. 2008, 39, 127-130. [CrossRef]

64. Malekitabar, H.; Ardeshir, A.; Sebt, M.H.; Stouffs, R. Construction Safety Risk Drivers: A BIM Approach. Saf. Sci. 2016, 82, 445-455. [CrossRef]

65. Rwamamara, R.; Holzmann, P. Reducing the Human Cost in Construction Through Design. In Proceedings of the 39th Nordic Ergonomics Society Conference, Lysekil, Sweden, 1-3 October 2007; Nordiska Ergonomisällskapet: Jönköping, Sweden, 2020.

66. Shafiq, M.T.; Afzal, M. Potential of Virtual Design Construction Technologies to Improve Job-Site Safety in Gulf Corporation Council. Sustainability 2020, 12, 3826. [CrossRef]

67. Sami Ur Rehman, M.; Thaheem, M.J.; Nasir, A.R.; Khan, K.I.A. Project Schedule Risk Management Through Building Information Modelling. Int. J. Constr. Manag. 2020, 1-11. [CrossRef]

68. Zhang, S.; Lee, J.-K.; Venugopal, M.; Teizer, J.; Eastman, C.M. A Framework for Automatic Safety Checking of Building Information Models. In Proceedings of the Construction Research Congress, West Lafayette, IN, USA, 21-23 May 2012; pp. 574-581. [CrossRef]

69. Zhang, S.; Boukamp, F.; Teizer, J. Ontology-Based Semantic Modeling of Construction Safety Knowledge: Towards Automated Safety Planning for Job Hazard Analysis (JHA). Autom. Constr. 2015, 52, 29-41. [CrossRef]

70. Pena, A.M.; Ragan, E.D. Contextualizing Construction Accident Reports in Virtual Environments for Safety Education. In Proceedings of the IEEE Virtual Reality (VR), Los Angeles, CA, USA, 18-22 March 2017. [CrossRef]

71. Froehlich, M.; Azhar, S. Investigating Virtual Reality Headset Applications for Construction. In Proceedings of the 52nd ASC Annual International Conference, Provo, UT, USA, 13-16 April 2016; Volume 23, pp. 13-16.

72. Limsupreeyarat, P.; Yabuki, N.; Tongthong, T. Toward the Improvement of Safety Planning for Construction Activities Performed at High Elevation by Using Augmented Reality. In Proceedings of the International Conference on Computing in Civil and Building Engineering, Nottingham, UK, 30 June-2 July 2010; Volume 30.

73. Chen, A.; Golparvar-Fard, M.; Kleiner, B. SAVES: A Safety Training Augmented Virtuality Environment for Construction Hazard Recognition and Severity Identification. In Proceedings of the 13th International Conference on Construction Applications of Virtual Reality, London, UK, 30-31 October 2013; Volume 30, pp. 373-384.

74. Chen, A.; Golparvar-Fard, M.; Kleiner, B. Design and Development of SAVES: A Construction Safety Training Augmented Virtuality Environment for Hazard Recognition and Severity Identification. J. Comput. Civ. Eng. 2013, 31, 841-848. [CrossRef]

75. Cheng, T.; Teizer, J. Real-Time Resource Location Data Collection and Visualization Technology for Construction Safety and Activity Monitoring Applications. Autom. Constr. 2013, 34, 3-15. [CrossRef]

76. Li, B.; Du, Z.; Xie, D.; Huang, L. Research on Engineering Construction Safety Integration Based on BIM and RFID. MATEC Web Conf. 2018, 246, 03035. [CrossRef]

77. Mohd, N.I.; Ali, K.N.; Bandi, S.; Ismail, F. Exploring Gamification Approach in Hazard Identification Training for Malaysian Construction Industry. Int. J. Built Environ. Sustain. 2019, 6, 51-57. [CrossRef]

78. Miller, G.A.; Dawood, N.N.; Kassem, M. Building an Emergent Learning Environment for Construction Health and Safety by Merging Serious Games and 4D Planning. In Proceedings of the International Conference on Computing in Civil Engineering, Clearwater Beach, FL, USA, 17-20 June 2012. [CrossRef] 
79. Golovina, O.; Teizer, J.; Pradhananga, N. Heat Map Generation for Predictive Safety Planning: Preventing Struck-By and near Miss Interactions Between Workers-On-Foot and Construction Equipment. Autom. Constr. 2016, 71, 99-115. [CrossRef]

80. Kumar, S.; Bansal, V.K. A GIS-Based Methodology for Safe Site Selection of a Building in a Hilly Region. Front. Archit. Res. 2016, 5, 39-51. [CrossRef]

81. Rajendran, S.; Clarke, B. Building Information Modeling: Safety Benefits and Opportunities. Prof. Saf. 2011, 56, 44-51.

82. Shang, Z.; Shen, Z. A Framework for a Site Safety Assessment Model Using Statistical 4D BIM-Based Spatial-Temporal Collision Detection. In Proceedings of the Construction Research Congress 2016, San Juan, Puerto Rico, 31 May-2 June 2016; Volume 6, pp. 2187-2196.

83. Zhou, Y.; Ding, L.Y.; Chen, L.J. Application of 4-D Visualization Technology for Safety Management in Metro Construction. Autom. Constr. 2013, 34, 25-36. [CrossRef]

84. Hu, Z.; Zhang, J. BIM- and 4D-Based Integrated Solution of Analysis and Management for Conflicts and Structural Safety Problems During Construction: 2. Development and Site Trials. Autom. Constr. 2011, 20, 167-180. [CrossRef]

85. Choi, B.; Lee, H.S.; Park, M.; Cho, Y.K.; Kim, H. Framework for Work-Space Planning Using Four-Dimensional BIM in Construction Projects. J. Constr. Eng. Manag. 2014, 140, 04014041. [CrossRef]

86. Choe, S.; Leite, F. Construction Safety Planning: Site-Specific Temporal and Spatial Information Integration. Autom. Constr. 2017, 84, 335-344. [CrossRef]

87. Sulankivi, K.; Kähkönen, K.; Mäkelä, T.; Kiviniemi, M. 4D-BIM for Construction Safety Planning. In Proceedings of the CIB 2010 World Congress Proceedings, Manchester, UK, 10-13 May 2010.

88. Jeelani, I.; Han, K.; Albert, A. Development of Immersive Personalized Training Environment for Construction Workers. In Proceedings of the ASCE International Workshop on Computing in Civil Engineering 2017, Seattle, WA, USA, 25-27 June 2017; Volume 2, pp. 408-415.

89. Sacks, R.; Whyte, J.; Swissa, D.; Raviv, G.; Zhou, W.; Shapira, A. Safety by Design: Dialogues Between Designers and Builders Using Virtual Reality. Constr. Manag. Econ. 2015, 33, 55-72. [CrossRef]

90. Pedro, A.; Le, Q.T.; Park, C.S. Framework for Integrating Safety into Construction Methods Education Through Interactive Virtual Reality. J. Prof. Issues Eng. Educ. Pract. 2016, 142, 04015011. [CrossRef]

91. Sacks, R.; Perlman, A.; Barak, R. Construction Safety Training Using Immersive Virtual Reality. Constr. Manag. Econ. 2013, 31, 1005-1017. [CrossRef]

92. Le, Q.T.; Pedro, A.; Park, C.S. A Social Virtual Reality Based Construction Safety Education System for Experiential Learning. J. Intell. Robot. Syst. 2015, 79, 487-506. [CrossRef]

93. Mo, Y.; Zhao, D.; Du, J.; Liu, W.; Dhara, A. Data-Driven Approach to Scenario Determination for VR-Based Construction Safety Training. In Proceedings of the Construction Research Congress 2018, New Orleans, LA, USA, 2-4 April 2018; Volume 2, pp. 116-125.

94. Luo, X.; Wong, C.K.; Chen, J. A multi-player virtual reality-based education platform for construction safety. In Proceedings of the 16th International Conference on Computing in Civil and Building Engineering, Osaka, Japan, 6-8 July 2016; pp. 1637-1643.

95. Teizer, J.; Cheng, T.; Fang, Y. Location Tracking and Data Visualization Technology to Advance Construction Ironworkers' Education and Training in Safety and Productivity. Autom. Constr. 2013, 35, 53-68. [CrossRef]

96. Zhao, D.; Lucas, J. Virtual reality simulation for construction safety promotion. Int. J. Inj. Control Saf. Promot. 2015, 22, 57-67. [CrossRef]

97. Hilfert, T.; Teizer, J.; König, M. First Person Virtual Reality for Evaluation and Learning of Construction Site Safety. In Proceedings of the 33rd International Symposium on Automation and Robotics in Construction (ISARC), Auburn, AL, USA, 18-21 July 2016; Volume 2. [CrossRef]

98. Creswell, J.W. Research Design: Qualitative, Quantitative, and Mixed Methods Approaches; SAGE Publications: Thousand Oaks, CA, USA, 2009.

99. Clevenger, C.; Puerto, C.; Glick, S.J. Interactive BIM-Enabled Safety Training Piloted in Construction Education. Adv. Eng. Educ. 2015, 4, 6 .

100. Chen, H.; Hou, L.; Zhang, G.K.; Moon, S. Development of BIM, IoT and AR/VR technologies for fire safety and upskilling. Autom. Constr. 2021, 125, 103631. [CrossRef]

101. WHO. Who Director General's Speeches. WHO Director-General's Opening Remarks at the Media Briefing on COVID-19. 2020. Available online: https://www.who.int/dg/speeches/detail/who-director-general-s-opening-remarks-at-the-media-briefingon-covid-19 (accessed on 11 March 2020).

102. Denny-Smith, G.; Sunindijo, R.Y.; Loosemore, M.; Williams, M.; Piggott, L. How Construction Employment Can Create Social Value and Assist Recovery from covid-19. Sustainability 2021, 13, 988. [CrossRef]

103. Khalfan, M.; Ismail, M. Engineering Projects and Crisis Management: A Descriptive Study on the Impact of COVID-19 on Engineering Projects in Bahrain. In Proceedings of the 2020 Second International Sustainability and Resilience Conference: Technology and Innovation in Building Designs(51154), Sakheer, Bahrain, 11-20 November 2020; pp. 1-5.

104. Caulkins, J.; Grass, D.; Feichtinger, G.; Hartl, R.; Kort, P.M.; Prskawetz, A.; Seidl, A.; Wrzaczek, S. How Long Should the COVID-19 Lockdown Continue? PLoS ONE 2020, 15, e0243413. [CrossRef] [PubMed]

105. Navon, R.; Kolton, O. Model for Automated Monitoring of Fall Hazards. J. Constr. Engineering Manag. 2006, 132, 733-740. [CrossRef]

106. Jannadi, O.A.; Almishari, S. Risk Assessment in Construction. J. Constr. Eng. Manag. 2003, 129, 492-500. [CrossRef] 